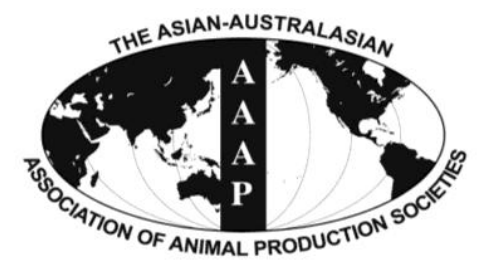

Asian-Aust. J. Anim. Sci.

Vol. 25, No. 4 : 577 - 583

April 2012

www.ajas.info

http://dx.doi.org/10.5713/ajas.2012.12012

\title{
Effects of Dietary Garlic Extract on Growth, Feed Utilization and Whole Body Composition of Juvenile Sterlet Sturgeon (Acipenser ruthenus)
}

\author{
Dong-Hoon Lee, Chang-Six Ra ${ }^{1}$, Young-Han Song ${ }^{1}$, Kyung-Il Sung ${ }^{1}$ and Jeong-Dae Kim ${ }^{1}$ ** \\ Gyenoggi Province Freshwater Fisheries Research Institute, 235-1 Kwangtan-Ri, \\ Yangpyeong-Gun, Gyeonggi-Do 476-841, Korea
}

\begin{abstract}
This study was carried out to investigate the supplemental effects of dietary garlic extract (GE) on growth performance of juvenile sterlet sturgeon (Acipenser ruthenus). The first experiment was designed to determine the optimum levels of garlic extract as growth promoter during 10 weeks. Three groups (two replicates/group) of 240 fish with mean body weight of $85 \mathrm{~g}$ were fed with diets containing 0 (control), 0.5 and $1.0 \%$ of GE. The highest weight gain (\%) and feed efficiency (\%) were found in fish groups fed with diet containing $0.5 \%$ GE. Subsequently, the supplemental effects of dietary GE was studied on growth of juvenile sterlet sturgeon (Acipenser ruthenus) with an average body weight of $59.6 \mathrm{~g}$. Fish cultured in freshwater were randomly allotted to each of 10 tanks (two groups of five replicates, 20 fish/tank) and fed diets with $0.5 \%$ GE or without GE (control), respectively, at the level of $2.0 \%$ of fish body weight per day for 5 weeks. Weight gain $(51.1 \%)$, feed efficiency $(79.1 \%)$, specific growth rate $(1.18 \%)$ and protein efficiency ratio (1.50) of fish fed $0.5 \%$ GE were significantly $(\mathrm{p}<0.05)$ higher than those fish fed the control diet. Significantly higher protein $(\mathrm{PRE} 20.4 \%)$ and lipid retention efficiencies (LRE, 74.5\%) were also found in $0.5 \%$ GE group $(\mathrm{p}<0.05)$. The present results suggested that dietary GE could improve growth and feed utilization of juvenile sterlet sturgeons. (Key Words : Acipenser ruthenus, Feed Utilization, Garlic Extract, Growth)
\end{abstract}

\section{INTRODUCTION}

Hormones, antibiotics and several other chemicals have been tested as growth promoters, antibacterial and for other purposes in aquatic animals (Jayaprakas and Sambhu, 1996; Masahiro, 1999), but their use in aquatic animal production cannot be recommended due to the residual effects in the muscle of fish as well as prawns. Plants are natural sources of safer and cheaper chemicals. Plant products have been reported to promote various activities like antistress, growth promotion, appetite stimulation and immunostimulation in aquaculture practices (Citarasu et al., 2001, 2002; Sivaram et al., 2004).

Garlic (Allium sativum) is a perennial bulb-forming plant that belongs to the genus Allium in the family

\footnotetext{
* Corresponding Author : Jeong-Dae Kim. Tel : +82-33-2508634, Fax : +82-33-2555482, E-mail : menzang@gmail.com

${ }^{1}$ Department of Animal Life System, College of Animal Life Sciences, Kangwon National University, Chuncheon 200-701, Korea.

Submitted Jan. 5, 2012; Accepted Jan. 25, 2012; Revised Jan. 31, 2012
}

Liliaceae, which has been used for centuries as a flavouring agent, traditional medicine, and a functional food to enhance physical and mental health. Garlic was studied in different forms of extracts: aqueous, ethanol and dried powder (Shin and Kim, 2004). It contains a variety of organosulfur compounds such as allicin, ajoene, S-allylcysteine, diallyl disulfide, S-methylcysteine sulfoxide and S-allylcysteine (Chi et al., 1982). Studies on garlic as an alternative of growth promoter in livestock production were conducted and its beneficial effects on growth, digestibility and carcass traits have been reported (Bampids et al., 2005; Tatara et al., 2008). Dietary garlic as a growth promoter in Nile tilapia (Oreochromis niloticus) improved body weight gain, feed intake and feed efficiency (Diab et al., 2002; Shalaby et al., 2006).

In Korea, sturgeon aquaculture has begun in 1996 with the main species for sterlet sturgeon (Acipenser ruthenus), Siberian (A. baeri), Russian (A. gueldenstaedti), Stellate (A. stellatus) and hybrid called bester (beluga femalexsterlet male). The sterlet is freshwater species which very rarely ascends the brackish water of rivers (Krayushina, 2006). 
Although sterlet sturgeon is known to be relatively easy to rear, its growth rate is slow reaching $50 \mathrm{~g}$ in the first year, $300 \mathrm{~g}$ in second year and $1 \mathrm{~kg}$ in the third year in pond farming condition (Hochleithner and Gessner, 1999).

Until now, no trial has been conducted to study the effect of dietary garlic extract on growth of sterlet sturgeon. This study was therefore designed to investigate the optimal level of dietary garlic extract and its effect on growth performance.

\section{MATERIALS AND METHODS}

\section{Preparation of garlic extract}

Two kg of garlic (Allium satium) powders obtained from the local market in Gyeonggi Province, Korea were left during $48 \mathrm{~h}$ in $99 \%$ ethanol $20 \mathrm{~L}(10 \% \mathrm{w} / \mathrm{v})$ at room temperature $\left(20 \pm 2^{\circ} \mathrm{C}\right)$, and the resulting extract was concentrated to $300 \mathrm{ml}$ using rotary evaporator (DPE 1210 NE Series, EYELA. Japan), giving the extract of $6.7 \mathrm{~g}$ of garlic powder/ml. This extract was sprayed on the diet after dilution in $300 \mathrm{ml}$ of distilled water.

\section{Experimental design and diets}

Juvenile sterlet sturgeons (Acipenser ruthenus) were obtained from Gyeonggi Province Freshwater Fisheries Research Institute, Gyeonggido, Korea. The first experiment was designed to determine the optimum levels of garlic extract as growth promoter. Three groups (two replicates/group) of 240 fish of a mean body weight of $85 \mathrm{~g}$ selected among 5,000 fish were randomly allotted to each of 6 tanks $(1.5 \times 1.5 \times 0.6 \mathrm{~m})$. The feeding experiment lasted 10 wk and was conducted in semi-recirculation freshwater system where water temperature and dissolved oxygen were maintained at $18 \pm 1^{\circ} \mathrm{C}$ and $>6 \mathrm{mg} \mathrm{O} / \mathrm{L}$, respectively. Flow rate was held at $8 \mathrm{~L} / \mathrm{min}$. A commercial extruded pellet of $2.2 \mathrm{~mm}$ size (Cargil Agri Purina Inc., Korea) was employed as the experimental diet. The analyzed composition was as follows: moisture $7.1 \%$, crude protein $47.6 \%$, crude fat $9.4 \%$ and crude ash $10.4 \%$. The diets were prepared to contain $0 \%$ GE (Control diet), 0.5\% GE (diet $20 \mathrm{~kg}+100 \mathrm{ml}$ garlic extract $+300 \mathrm{ml}$ distilled water), $1.0 \% \mathrm{GE}($ diet $20 \mathrm{~kg}$ $+200 \mathrm{ml}$ garlic extract $+300 \mathrm{ml}$ distilled water) garlic extract. The mixture of garlic extract and distilled water was sprayed on the experimental diets, which were then dried in a dryer (GCT-104OR-4G, Fresh and Cool Technology Ltd., Korea) at $30^{\circ} \mathrm{C}$ for $48 \mathrm{~h}$ in order to volatilize remaining ethanol. Diets at the level of $4 \%$ body weight/d were supplied three times daily at 08:00 h, 13:00 h and 18:00 h, respectively. All diets were stored in air-tight containers at $-20^{\circ} \mathrm{C}$ until used.

The second trial was carried out to investigate the supplemental effect of dietary garlic extract on growth of juvenile sterlet sturgeon with average body weight $59.6 \mathrm{~g}$.
Two hundred fish selected from a stock of 2,000 fish were randomly allotted to each of 10 tanks (two groups of five replicates, 20 fish/tank). Fish were cultured in semirecirculation freshwater system. Water temperature and dissolved oxygen levels were kept at $22 \pm 1{ }^{\circ} \mathrm{C}$ and $>6 \mathrm{mg} \mathrm{O} \mathrm{O}_{2} / \mathrm{L}$, respectively. Flow rate was adjusted at a minimum of $3 \mathrm{~L} / \mathrm{min}$. A commercial extruded pellet of 1.7 mm size (Cargil Agri Purina Inc., Korea) was used as the experimental diet. The diet was chemically analyzed to contain moisture $9.2 \%$, crude protein $47.8 \%$, crude fat $8.9 \%$ and crude ash $8.8 \%$ (As-is basis). GE diet was prepared using the same method as first experiment of which chemical composition was analyzed to be same (moisture $9.6 \%$, crude protein $47.6 \%$, crude fat $8.7 \%$ and crude ash $8.8 \%$ ). Five replicate groups of fish were fed diet with (GE) or without (CD) garlic extract, respectively by hand at the rate of $2 \%$ of fish body weight per day at 08:00 $\mathrm{h}, 13: 00 \mathrm{~h}$ and 18:00 h, respectively for $5 \mathrm{wk}$. For both first and second experiments, all fish were individually weighed to ensure a homogeneous sampling at the beginning of the experiment and this process was repeated every second week.

\section{Sample collection and analysis}

At the end of the first and second feeding trials, fish were anesthetized with AQUES (Handong Co. Ltd., Korea) and individually weighed and counted for calculation of weight gain (WG), feed efficiency (FE), specific growth rate (SGR), protein efficiency ratio (PER) and survival rate. In second trial, fifteen fish (three fish per tank) from each group were selected at equivalent weight to analyze wholebody proximate. And five fish (one fish per tank) from each group were selected at equivalent weight to determine hepatosomatic index (HSI) and condition factor (CF). Chemical analyses of diets and fish whole body were performed by the standard procedure of AOAC (1995) for moisture, crude protein and crude ash. Crude lipid was determined using the Soxtec system 1046 (Tecator AB, Sweden) after freeze-drying the samples for $12 \mathrm{~h}$.

\section{Statistical analysis}

Data of Exp. 1 (final weight, WG, FE and SGR) and Exp. 2 (final weight, WG, FE, SGR, PER, proximate composition and retention efficiency) were analyzed using one-way analysis of variance (ANOVA) and significant differences among treatment means were compared using Duncan's multiple range test (Duncan, 1955). Significance was tested at 5\% level and all statistical analyses were carried out using the SPSS Version 10 (SPSS, Michigan Avenue, Chicago, IL, USA). Statistical analysis among individuals having single value without replicate within group, such as HSI and CF levels of significant, were evaluated by the Wilcoxon test and Friedman test 
Table 1. Growth performance of juvenile sterlet sturgeon fed diets with or without garlic extracts (GE) for $10 \mathrm{wk}^{1}$

\begin{tabular}{|c|c|c|c|}
\hline \multirow{2}{*}{ Item } & \multicolumn{3}{|c|}{ Experimental groups } \\
\hline & Control & $0.5 \% \mathrm{GE}$ & $1 \% \mathrm{GE}$ \\
\hline Initial weight (g/fish) & $85.2 \pm 0.79$ & $85.2 \pm 0.75$ & $85.2 \pm 0.72$ \\
\hline p-value ${ }^{2}$ & 0.72 & 0.56 & 0.61 \\
\hline Final weight (g/fish) & $246.0 \pm 6.48^{\mathrm{b}}$ & $264.3 \pm 6.35^{\mathrm{a}}$ & $258.9 \pm 5.01^{\mathrm{a}}$ \\
\hline p-value ${ }^{3}$ & 0.32 & 0.27 & 0.41 \\
\hline WG $(\%)^{4}$ & $188.5 \pm 2.01^{\mathrm{b}}$ & $210.0 \pm 1.77^{\mathrm{a}}$ & $205.3 \pm 4.53^{\mathrm{a}}$ \\
\hline $\mathrm{FE}(\%)^{5}$ & $85.7 \pm 0.81^{\mathrm{b}}$ & $97.4 \pm 0.78^{\mathrm{a}}$ & $97.0 \pm 2.14^{\mathrm{a}}$ \\
\hline $\operatorname{SGR}(\%)^{6}$ & $1.51 \pm 0.02^{\mathrm{b}}$ & $1.62 \pm 0.01^{\mathrm{a}}$ & $1.59 \pm 0.01^{\mathrm{a}}$ \\
\hline $\operatorname{HSI}^{7}(\mathrm{n}=5)$ & $2.04 \pm 0.06^{\mathrm{b}}$ & $2.58 \pm 0.13^{\mathrm{a}}$ & $2.63 \pm 0.12^{\mathrm{a}}$ \\
\hline $\mathrm{CF}^{8}(\mathrm{n}=5)$ & $1.74 \pm 0.07^{\mathrm{b}}$ & $1.85 \pm 0.21^{\mathrm{a}}$ & $1.78 \pm 0.06^{\mathrm{b}}$ \\
\hline Survival (\%) & 100 & 100 & 100 \\
\hline
\end{tabular}

${ }^{1}$ Values (means \pm SD) were calculated from each of 80 fish per group. Means with different superscripts in the same row are significantly different $(\mathrm{p}<0.05)$.

${ }^{2,3}$ In each experimental replicate, 40 data were used. $\mathrm{p}>0.05$ was considered to be statistically homogeneous samples between replicates.

${ }^{4}$ Weight gain $(\%)=($ final weight $(\mathrm{g})$-initial weight $(\mathrm{g})) \times 100 /$ initial weight $(\mathrm{g})$.

${ }^{5}$ Feed efficiency $(\%)=$ wet weight gain $(\mathrm{g}) \times 100 /$ feed intake $(\mathrm{g}, \mathrm{DM})$.

${ }^{6}$ Specific growth rate $=(\mathrm{Ln}$ final weight $(\mathrm{g})-\mathrm{Ln}$ initial weight $(\mathrm{g})) /$ experimental days.

${ }^{7}$ Hepatosomatic index $(\%)=$ live liver weight $(\mathrm{g}) \times 100 /$ body weight $(\mathrm{g})$.

${ }^{8}$ Condition factor $=\left(\right.$ fish weight $(\mathrm{g}) /$ fish length $\left.(\mathrm{cm})^{3}\right) \times 100$.

(Zimmerman and Zumbo, 1993). Statistical significance of the differences was determined by a significant level of $5 \%$ $(\mathrm{p}<0.05)$.

\section{RESULTS}

\section{Growth performance}

In the first trial, fish groups fed diet with garlic extract (GE) exhibited significant improvement in body weight, weight gain, feed efficiency and condition factor as compared to those fed with control diet for $10 \mathrm{wk}$ (Table 1). No mortality was recorded in all fish groups during the experimental period. Final fish weight was highest in fish fed $0.5 \% \mathrm{GE}(264 \mathrm{~g}$ ), while the lowest (246 g) was found in fish fed control diet, showing weight gain (WG) of $210 \%$ and $188 \%$, respectively. Feed efficiency (FE) ranged from $79.7 \%$ (control) to $88.7 \%$ (0.5\% GE). Even though WG and FE of fish fed $1.0 \%$ GE were slightly lower than those of fish fed $0.5 \% \mathrm{GE}$, those were not significantly different ( $>0.05)$ from each other. The highest hepatosomatic index (HSI) of $2.63 \%$ was obtained in fish fed $1.0 \% \mathrm{GE}$, while control group showed the lowest value of $2.04 \%$. Condition factor $(\mathrm{CF})$ was highest $(1.85 \%)$ in $0.5 \%$ GE group which was significantly different $(\mathrm{p}<0.05)$ from the other two groups. No significant differences were found between two replicates of each experimental group.

Results of growth performance of sterlet sturgeon fed two experimental diets for $5 \mathrm{wk}$ in second experiment are summarized in Table 2. No mortality was recorded in all fish groups during the experimental periods. At the end of the experiment, fish fed $0.5 \%$ GE showed final weight higher than those fed control diet. An improved specific growth rate (SGR) was obtained in fish fed $0.5 \% \mathrm{GE}$ $(1.18 \%)$ compared to control group (1.09\%). FE was $66.9 \%$

Table 2. Growth performance of juvenile sterlet sturgeon fed diets with or without garlic extracts (GE) for $5 \mathrm{wk}^{1}$

\begin{tabular}{|c|c|c|}
\hline \multirow{2}{*}{ Item } & \multicolumn{2}{|c|}{ Experimental groups } \\
\hline & Control & $0.5 \% \mathrm{GE}$ \\
\hline Initial weight (g/fish) & $59.8 \pm 0.43$ & $60.2 \pm 0.63$ \\
\hline p-value ${ }^{2}$ & 0.99 & 0.95 \\
\hline Final weight (g/fish) & $85.6 \pm 2.12$ & $91.4 \pm 1.93 *$ \\
\hline p-value ${ }^{3}$ & 0.85 & 0.99 \\
\hline WG $(\%)^{4}$ & $46.4 \pm 3.61$ & $51.1 \pm 1.09 *$ \\
\hline $\operatorname{FE}(\%)^{5}$ & $66.9 \pm 4.48$ & $79.1 \pm 1.59^{*}$ \\
\hline $\operatorname{SGR}(\%)^{6}$ & $1.09 \pm 0.07$ & $1.18 \pm 0.02 *$ \\
\hline $\mathrm{PER}^{7}$ & $1.27 \pm 0.08$ & $1.50 \pm 0.03 *$ \\
\hline $\operatorname{HSI}^{8}(\mathrm{n}=5)$ & $2.09 \pm 0.19$ & $2.27 \pm 0.20$ \\
\hline $\mathrm{CF}^{9}(\mathrm{n}=5)$ & $1.27 \pm 0.06$ & $1.34 \pm 0.03 *$ \\
\hline Survival (\%) & 100 & 100 \\
\hline
\end{tabular}

${ }^{1}$ Values are means $\pm \mathrm{SE}$ of five replicates for each of two fish groups. Means with the asterisk* in the same row are significantly different $(\mathrm{p}<0.05)$ between two groups.

${ }^{2,3}$ In each experimental replicates, 20 data were used. $p>0.05$ was considered to be statistically homogeneous samples between replicates.

${ }^{4}$ Weight gain $(\%)=($ final weight $(\mathrm{g})$-initial weight $(\mathrm{g})) \times 100 /$ initial weight.

${ }^{5}$ Feed efficiency $(\%)=$ wet weight gain $(\mathrm{g}) \times 100 /$ feed intake $(\mathrm{g}, \mathrm{DM})$.

6 Specific growth rate $=(\mathrm{Ln}$ final weight $(\mathrm{g})-\mathrm{Ln}$ initial weight (g))/experimental days.

${ }^{7}$ Protein efficiency ratio $=$ wet weight gain $(\mathrm{g}) /$ protein intake.

${ }^{8}$ Hepatosomatic index $=$ liver weight $(\mathrm{g}) \times 100 /$ body weight $(\mathrm{g})$.

${ }^{9}$ Condition factor $=\left(\right.$ fish weight $(\mathrm{g}) /$ fish length $\left.(\mathrm{cm})^{3}\right) \times 100$. 
for control and $76.9 \%$ for $0.5 \%$ GE group. Protein efficiency ratio (PER) was higher (1.50) in $0.5 \%$ GE group than in control (1.27). Higher $\mathrm{CF}$ was also found in $0.5 \%$ GE group (1.34). All these parameters were significantly different $(\mathrm{p}<0.05)$ between two groups. However, HSI was not significantly different ( $p>0.05$ ) between two groups. No significant differences were found among five replicates of each experimental group.

\section{Whole body proximate compositions}

The whole body proximate composition of initial and final sturgeon fed diets with or without garlic extract during $5 \mathrm{wk}$ is shown Table 3. At the beginning and end of feeding trials, three fish per replicate (five replicates per initial and each final group, respectively) were selected in order to analyze whole body composition. Moisture content was decreased from $77.5 \%$ to $77.2 \%$ for two fish groups, which was however not significantly different $(p>0.05)$. While protein slightly decreased from $13.8 \%$ to $13.1 \%$ whereas, lipid greatly increased from $4.8 \%$ to $5.4 \%$ and $6.1 \%$ for control and $0.5 \%$ GE, respectively. However, a significant different was not observed $(p>0.05)$ between initial and control groups. Ash was significantly lower $(\mathrm{p}<0.05)$ in $0.5 \%$ GE compared to those in initial and control groups. Based on nutrient gain and dry nutrient intake (Kim and Shin, 2006), protein (PRE) and lipid (LRE) retention efficiencies (\%) were calculated for two experimental groups (Table 3). PRE was slightly higher in fish fed $0.5 \%$ GE $(20.4 \%)$ than in fish fed control $(18.1 \%)$ diet, while LRE was much higher in the former $(74.5 \%)$ than in the latter $(46.6 \%)$ group. A significant difference $(\mathrm{p}<0.05)$ in both PRE and LRE was found between two groups.

\section{DISCUSSION}

There is no standard practical grow-out diet for sturgeon.
In Korea, only few diets have been used by fish farmers but these diets are still under research and development. Also, most sturgeon farmers in Korea use diets commercially available, particularly those for salmonid and Korean rock fish. Hung et al. (1998) fed $72 \mathrm{~g}$ white sturgeon one of seven commercial salmonid diets or a purified diet for $8 \mathrm{wk}$. These diets contained 5.9 to $8.3 \%$ moisture, 31.5 to $51.4 \%$ crude protein, 7.6 to $19.4 \%$ lipid and 3.8 to $11.7 \%$ ash and diet proximate composition of the best growth and feed efficiency was $4.5 \%$ moisture, $51.4 \%$ crude protein, $18.0 \%$ lipid and $11.7 \%$ ash. Nutritional needs for sterlet sturgeon still remain to be elucidated. Control diet used in the present study was a commercial diet for Korean rock fish which contained moisture of $9.2 \%$, crude protein of $52.6 \%$, crude fat of $9.7 \%$ and crude ash of $9.7 \%$. This diet had lower crude lipid (5 to $8 \%$ ) than that of salmonid diet (15 to $18 \%$, Cargil Agri Purina, Inc.) manufactured in Korea. Nevertheless, the reason that we employed this diet in the study was to prevent high mortality due to increased disease outbreak. In the light of past 12 years culture experience for sterlet sturgeon, high mortality occurred when salmonid diets were fed. Therefore, the aim of this study was to investigate if the sturgeon could exert any improvement on growth and feed utilization when garlic extract was added into the commercial diet for rock fish.

Various extracts from herbs and spices are reported to improve animal performance by stimulating action on gut secretions or by having a direct bactericidal effect on gut microflora and furthermore the herbals active principles in the diets induce the secretion of the digestive enzyme and the growth promoter in herbs induced high protein synthesis (Citarasu, 2010). Garlic is an important medicinal herb extensively cultivated in many countries and has played an important dietary function as well as medicinal role for centuries. There is a lot of anecdotal evidence about the use and effectiveness of garlic for fish. Much of this is positive,

Table 3. Proximate composition (\%, as-is basis) of whole body and protein and lipid retention efficiencies of juvenile sterlet sturgeon fed diets with or without garlic extracts (GE) for $5 \mathrm{wk}^{1}$

\begin{tabular}{lccc}
\hline Item & \multicolumn{3}{c}{ Experimental groups } \\
\cline { 2 - 4 } & Initial & Control & $0.5 \%$ GE \\
\hline Proximate composition (\%) & & & $77.2 \pm 0.23^{\mathrm{a}}$ \\
$\quad$ Moisture & $77.5 \pm 0.31^{\mathrm{a}}$ & $77.2 \pm 0.24^{\mathrm{a}}$ & $13.1 \pm 0.25^{\mathrm{b}}$ \\
Crude protein & $13.8 \pm 0.14^{\mathrm{a}}$ & $13.1 \pm 0.24^{\mathrm{b}}$ & $6.1 \pm 0.32^{\mathrm{a}}$ \\
Crude lipid & $4.8 \pm 0.39^{\mathrm{b}}$ & $5.4 \pm 0.39^{\mathrm{b}}$ & $2.5 \pm 0.23^{\mathrm{b}}$ \\
Crude ash & $2.9 \pm 0.11^{\mathrm{a}}$ & $3.0 \pm 0.13^{\mathrm{a}}$ & \\
Retention efficiency (\%) & & & $20.4 \pm 1.38^{*}$ \\
PRE $(\%)^{2}$ & - & $18.1 \pm 0.32$ & $74.5 \pm 1.14^{*}$ \\
LRE $(\%)^{3}$ & - & $46.6 \pm 1.47$ & \\
\hline
\end{tabular}

\footnotetext{
${ }^{1}$ Values are means \pm SE of five replicates with 3 determinations per replicate for initial and each final group. Means with different superscripts in the same row are significantly different $(\mathrm{p}<0.05)$. Means with the asterisk* in same row are significantly different $(\mathrm{p}<0.05)$ between two experimental groups.

${ }^{2}$ Protein retention efficiency $(\%)=$ Body protein gain $(\mathrm{g}) /$ dry protein intake $(\mathrm{g}) \times 100$.

${ }^{3}$ Lipid retention efficiency $(\%)=$ Body lipid gain $(\mathrm{g}) /$ dry lipid intake $(\mathrm{g}) \times 100$.
} 
but there are also negative anecdotal reviews of the use of garlic. Garlic is used as food for humans as well as some animals and as remedy for several diseases, as reported in folk medicine (Shalaby et al., 2006). Several herbs such as garlic, onion, marjoram, caraway, basil, anise, fennel, licorice, black seed and fenugreek have been tested for growth promoting activities (Jayaprakas and Eupharsia 1996; Citarasu et al., 2002; Sivaram et al., 2004), feed conversion (Shalaby et al., 2003; El-Darkar et al., 2004a,b; Shalaby, 2004), and improvement of protein digestibility and energy retention (El-Dakar et al., 2004a,b) in aquatic animals.

The addition of the garlic extract showed a significant improvement in weight gain and feed efficiency of sterlet sturgeon in $10 \mathrm{wk}$ trial (Table 1). However, those parameters were not significantly different between 0.5 and $1 \%$ GE groups, while condition factor was highest in $0.5 \%$ GE group among treatments. From these results, it was concluded that the addition of $0.5 \%$ GE to commercial diet was optimal for growth performance of sterlet sturgeon. In second trial, fish were fed diets with $(0.5 \% \mathrm{GE})$ and without GE for $5 \mathrm{wk}$. In all parameters investigated, fish fed diet $0.5 \%$ GE showed a significant improvement (Table 2). In agreement with the present results, Shalaby et al. (2006) reported significant increased weight gain, feed efficiency, protein efficiency ratio (PER) and specific growth rate (SGR) in Nile tilapia which were fed diet containing garlic powder of $30.0 \mathrm{~g} / \mathrm{kg}$ diet. Similarly, Diab et al. (2002) mentioned feeding diet with $2.5 \%$ garlic/ $\mathrm{kg}$ diet resulted in the highest growth performance in O. niloticus. In the same species, Abou-Zeid (2002) found a positive improvement in biomass and specific growth rate with garlic supplementation. Metwally (2009) also mentioned that the best performance was obtained in Nile tilapia fed diet with garlic powder of $32 \mathrm{~g} / \mathrm{kg}$ diet. A significant increase in growth, feed conversion and protein efficiency was shown in rainbow trout when fed diet with $1.0 \%$ garlic (Nya and Austin, 2009).

Protein efficiency ratio and feed efficiency are utilized as quality indicator for fish diet and its amino acid balance. Therefore, these factors are used to evaluate protein utilization and turnover (Shalaby et al., 2006). The present results are also in agreement with those obtained by Khattab et al. (2004) who found that the diet of Biogen ${ }^{\circledR}$ increased feed intake, feed conversion ratio (FCR) and PER in fish. In contrast to these results, Sahu et al. (2007) reported that SGR and FCR in fish (Labeo rohita) fed with $0.5,1 \%$ garlic powder/kg diet was not significantly different as compared with those of the control. In livestock, a few research suggested that garlic did not affect growth performance (Horton et al., 1991; Freitas et al., 2001; Bampidis et al., 2005) because the pungent smell which may lead to lower diet palatability.
In the present study, HSI was higher in fish fed $0.5 \%$ garlic extract than in control. HSI provides an indication on status of energy reserve in an animal. In a poor environment, fish usually have a smaller liver (with less energy reserved in the liver). In crustacea, relative weight of hepatopancreas, which plays a key role in food assimilation (Dhall and Moriaty, 1984) probably manifests the provision for energy utilization for growth and metabolism. Sagi and Ra'anan (1988) found that the relative size of hepatopancreas was highly correlated with the morphotypic stage of development and its relative energy expenditure in growth and sexual activity. Also, Cohen et al. (1981) and Sagi and Ra'anan (1988) suggested that cause of lower HSI retarded growth of prawn.

Kamruzzaman, et al. (2011) reported that nitrogen (N) retention is considered as an important index of protein status in ruminants and $\mathrm{N}$ digestibility, $\mathrm{N}$ absorption and $\mathrm{N}$ retention were numerically higher in GS-diet with garlic stem and leaf silage than hay-diet, although $\mathrm{N}$ intake was similar. Probably, due to nature of the plants and plenty of bioactive components present in garlic, these parameters might have a positive impact on $\mathrm{N}$ balance by influencing microbial proteolytic activities of rumen fluid in sheep and fed with GS-diet. Oi et al. (2001) reported that protein anabolism occurs in rats fed the high protein diet supplemented with garlic. Wanapat et al. (2008) found significantly higher digestibility, absorption and retention of $\mathrm{N}$ in garlic powder supplemented groups compared to control group. Our present finding also accords with these results that juvenile sterlet sturgeon fed diet with garlic extract has higher $\mathrm{N}$ utilization (PRE, \%) than control group.

Dietary lipids are important nutrients affecting energy production in most of fish and essential for growth and development. But, fish are known to utilize protein preferentially to lipid or carbohydrate as an energy source. Lipids are stored in several tissues at high levels in sturgeon. Sturgeon may have muscle lipid content as high or higher than that of other fish that are considered fatty, such as salmon and mackerel (Krzynowek and Murphy, 1987). Sturgeon fed high lipid diets preferentially deposits lipid in the liver and the digestive tract rather than in muscle (Decker et al., 1991). In present study, lipid in whole body composition of juvenile sterlet sturgeon was greatly increased from $4.8 \%$ for initial to $5.4 \%$ and $6.1 \%$ for control and $0.5 \%$ GE group, respectively. Dietary garlic extract might result in excessive lipid aggregation in whole body because increase in protein utilization for fish fed GE diet could reduce role of lipid as an energy source for growth, so deposition of lipid was higher in GE group than in control. Although there is constant controversy concerning the effect of garlic as growth promoter for fish, the present results suggest that dietary garlic for juvenile sterlet sturgeon (60 to $250 \mathrm{~g}$ ) could positively affect growth 
performance and feed utilization.

\section{ACKNOWLEDGEMENTS}

We would like to thank Gyeonggi Province Freshwater Fisheries Research Institute for donating the fish and providing the facility.

\section{REFERENCES}

Abou-Zeid, S. M. 2002. The effect of some medical plant on reproductive and productive performance of Nile tilapia fish Cairo: Cairo University, Faculty of Agriculture, p. 212. (Ph. D. Thesis)

AOAC. 1995. Official methods of analysis. 16th ed. Association of Official Analytical Chemists. Arlington, Virginia, USA.

Bampidis, V. A., V. Christodoulou, E. Christaki, P. Florou-Paneri and A. B. Spais. 2005. Effect of dietary garlic bulb and garlic husk supplementation on performance and carcass characteristics of growing lambs. Anim. Feed Sci. Technol. 121:273-283

Chi, M. S., E. T. Koh and T. J. Steward. 1982. Effects of garlic on lipid metabolism in rats fed cholesterol or lard. J. Nutr. 112:241-248.

Citarasu, T., M. M. Babu, S. M. J. Punitha, K. Venket Ramalingam and M. P. Marian. 2001. Control of pathogenic bacteria using herbal biomedicinal products in the larviculture system of Penaeus monodon. International Conference on Advanced Technologies in Fisheries and Marine Sciences, MS University, India.

Citarasu, T., R. R. Sekar, M. M. Babu and M. P. Marian. 2002. Developing Artemia enriched herbal diet for producing quality larvae in Penaeus monodon. Asian. Fish. Sci. 15:21-32.

Citarasu, T. 2010. Herbal biomedicines: a new opportunity for aquaculture industry. Aquac. Int. 18:403-414.

Cohen, D., Z. Ra'anan and T. Brody. 1981. Population profile development and morphotypic differentiation in giant freshwater prawn Macrobrachium rosenbergii. J. World Maricult. Soc. 12:231-243.

Decker, E. A., A. D. Crum, S. D. Mims and J. H. Tidwell. 1991. Processing yield and composition of paddlefish (Polyodon spathula), a potential aquaculture species. J. Agric. Food Chem. 39:686-688.

Dhall, W. and D. J. W. Moriaty. 1984. Functional aspects of nutrition and digestion: the midgut. In: The Biology of Crustacea (Ed. D. E. Bliss and L. H. Mantel), Vol. 5, Internal Anatomy and Physiological Regulation. Academic Press, Orlando, FL, pp. 215-251.

Diab, A. S., G. O. El-Nagar and Y. M. Abd-El-Hady. 2002. Evaluation of Nigella sativa L (black seeds; baraka), Allium sativum (garlic) and BIOGEN as feed additives on growth performance and immunostimulants of $O$. niloticus fingerlings. Suez Canal Vet. Med. J. 745-775.

Duncan, D. B. 1955. Multiple range and multiple ' $F$ 'tests. Biometrics 11:1-42.

El-Dakar, A. Y., G. D. I. Hassanien, S. S. Gad and S. E. Sakr. 2004a. Use of medical and aromatic plants in fish diets: I. Effect of dried marjoram leaves on performance of hybrid tilapia Oreochromis niloticus $\times$ Oreochromis auraus, fingerlings. J. Egypt. Acad. Soc. Environ. Dev. (B. Aquacult.) 5:67-83.

El-Dakar, A. Y., G. D. I. Hassanien, S. S. Gad and S. E. Sakr. 2004b. Use of medical and aromatic plants in fish diets: 2 . Effect of dried basil leaves on performance of hybrid tilapia Oreochromis niloticus $\times$ Oreochromis auraus, fingerlings. 3rd Inter. Conf. on Animal Production and Health in Semi-Arid Areas, Suez Canal University, pp. 265-277.

Freitas, R., J. B. Fonseca, R. T. Soares, H. S. Rostagn and P. R. Soares. 2001. Utilization of garlic (Allium sativum L.) as growth promoter of broilers. Rev. Bras. Zootec. 30:761-765.

Hochleithner, M. and J. Gessner. 1999. The sturgeon and paddlefish (Acipenseriformes) of the world. Biology and Aquaculture. AquaTech publications. p. 165.

Horton, G. M. J., D. B. Blethen and B. M. Prasad. 1991. The effect of garlic (Allium sativum) on feed palatability of horses and feed consumption, selected performance, and blood parameters in sheep and swine. Can. J. Anim. Sci. 71:607-610.

Hung, S. S. O., F. S. Conte and F. Frost. 1998. Growth of white sturgeon fed seven commercial feeds. Aquaculture 161:89.

Jayaprakas, V. and J. Eupharsia. 1996. Growth performance of Labeo rohita (Ham.) Livol (IHF-1000), an herbal product. Proc. Indian Natl. Sci. Acad. 63:1-10.

Jayaprakas, V. and C. Sambhu. 1996. Growth response of white prawn, Penaeus indicus to dietary L-carnitine. Asian. Fish. Sci. 9:209-219.

Kamruzzaman, M., A. Torita, Y. Sako, M. Al-Mamun and H. Sano. 2011. Effects of feeding garlic stem and leaf silage on rates of plasma leucine turnover, whole body protein synthesis and degradation in sheep. Small Rumin. Res. 99:37-43.

Kim, J. D. and S. H. Shin. 2006. Growth, feed utilization and nutrient retention of juvenile olive flounder (Paralichthys olivaceus) fed moist, semi-moist and extruded diets. AsianAust. J. Anim. Sci. 19:720-726.

Krayushkina, L. S. 2006. Considerations on evolutionary mechanisms of osmotic and ionic regulation in Acipenseridae: an overview. J. Appl. Ichthyol. 22:70-76.

Krzynowek, J. and J. Murphy. 1987. Prozimate composition, energy, fatty acid, sodium and cholesterol content finfish, shellfish, and their product. National Oceanic Atmosphere Administration Technical Report 55:1-48.

Khattab, Y. A., A. M. S. Shalaby, S. M. Sharaf, H. I. EL-Marakby and E. H. Rizhalla. 2004. The physiological changes and growth performance of the Nile tilapia Oerochromis niloticus after feeding with Biogen ${ }^{\circledR}$ as growth promoter. Egypt J. Aquatic Biol. Fish 8:145-158

Masahiro Sakai. 1999. Current research status of fish immunostimulants. Aquaculture 172:63-92.

Metwally, M. A. A. 2009. Effects of garlic (Allium sativum) on some antioxidant activities in Tilapia nilotica (Oreochromis niloticus). World J. Fish Mar. Sci. 1:56-64.

Nya, E. J. and B. Austin. 2009. Use of garlic, Allium sativum, to control Aeromonas hydrophila infection in rainbow trout, Oncorhynchus mykiss (Walbaum). J. Fish Dis. 32:963-970.

Oi, Y., M. Imafuku, C. Shishido, Y. Kominato, S. Nishimura and K. Iwai. 2001. Garlic supplementation increases testicular testosterone and decreases plasma corticosterone in rats fed a high protein diet. J. Nutr. 131:2150-2156.

Sagi, A. and Z. Ra'anan. 1988. Morphotypic differentiation of 
male of the fresh-water prawn Macrobrachium rosenbergii: changes in the midgut glands and the reproductive system. J. Crustacean Biol. 8:43-47.

Sahu, S., B. K. Das, B. K. Mishra, J. Pradhan and N. Sarangi. 2007. Effect of Allium sativum on the immunity and survival of Labeo rohita infected with Aeromonas hydrophila. J. Appl. Ichthyol. 23:80-86.

Shalaby, A. M., Y. M. Khattab and A. M. Abdel rahman. 2006. Effects of garlic (Allium sativum) and chloramphenicol on growth performance, physiological parameters and survival of Nile Tilapia (Oreochromis niloticus). J. Venom. Anim. Toxins Incl. Trop. Dis. 12:172-201.

Shalaby, S. M. M., A. I. Abd Elmonem and A. Y. El-Dakar. 2003. Enhancement of growth performance, feed and nutrient utilization of Nile tilapia (Oreochromis niloticus), using of licorice roots (Erksous) as a feed attractive. J. Egypt. Acad. Soc. Environ. Develop. (B-Aquaculture), 4:119-142.

Shalaby, S. M. M. 2004. Response of Nile tilapia, Oreochromis niloticus, fingerlings to diets supplemented with different levels of fenugreek seeds (Hulba). J. Agric. Mansoura Univ., 29:2231-2242.
Shin, S. H. and M. K. Kim. 2004. Effect of dired powders or ethanol extracts of garlic flesh and peel on lipid metabolism and antithrombogenic capacity in 16-month-old rats. Hanguk Yongyang Hakhoechi. 37:515-524.

Sivaram, V., M. M. Babu, T. Citarasu, G. Immanuel, S. Murugadass and M. P. Marian. 2004. Growth and immune response of juvenile greasy groupers (Epinephelus tauvina) fed with herbal antibacterial active principle supplemented diets against Vibrio harveyi infections. Aquaculture 237:9-20.

SPSS. Inc. 1999. SPSS Base 10.0 for Windows User's Guide. SPSS Inc., Chicago IL.

Tatara, M. R., E. Sliwa, K. Dudek, A. Gawron and T. Piersiak. 2008. Aged garlic extract and allicin improve performance and gastrointestinal tract development of piglets reared in artificial sow. Ann. Agric. Environ. Med. 15:63-69.

Wanapat, M., P. Khejornsart, P. Pakdee and S. Wanapat. 2008. Effect of supplementation of garlic powder on rumen ecology and digestibility of nutrients in ruminants. J. Sci. Food Agric. 88:2231-2237.

Zimmerman, D. W. and B. D. Zumbo. 1993. Relative power of the Wilcoxon test, the friedman test, and repeated-measures ANOVA on ranks. J. Exp. Educ. 62:75-86. 